\title{
Experimentation on Geopolymer Concrete Added with Fly Ash
}

\author{
Anish C, Sathish Kumar K, Rajesh S
}

\begin{abstract}
The technique for living and the speedy headway of advancement have provoked an extension in the total and sort of waste made, inciting waste exchange crisis. This investigation takes care of the issue of the plastic transfer emergency in condition. So as to contain certain waste, reuse of some waste materials can be supplanted in the relational word of cement. The squanders which are reused in this venture utilizes diverse level of waste plastics in cement. This monitors normal assets and illuminates a developing waste transfer emergency. Squander plastic are supplant somewhat with coarse total $(0 \%, 1 \%, 2 \%$ and 3\%). In this present examination, numerous research facility tests were done for the assessment of properties of OPC on substitutions. The tests are compressive quality, flexural quality, and circuitous elasticity (parting). At last the test outcomes are contrasted and ordinary cement.
\end{abstract}

Keywords - Ordinary Portland cement, Silica fume, Geopolymer concrete

\section{INTRODUCTION}

During the continuous decades, staggering advances have been taken in improving the display of concrete as an improvement material[1]-[8]. Particularly Silica Fume and fly flotsam and jetsam independently or in a blend are key in progress of top notch bond for sober minded application. The use of silica rage as a pozzolana has extended in general thought over the continuous years since when suitably used it as certain percent, it can improve various properties of concrete both in the fresh similarly as in set states like before quality cohesiveness, quality, subjugation permeability and strength. The key goals of using fly trash in top notch concrete are to decrease heat age and to acquire better strength properties[9]-[15].

Waterway sand which is most usually utilized as fine total in the creation of cement and mortar has the issue of intense deficiency and debasement issues in numerous territories. Simultaneously expanding amount of squashed stone is accessible from smashers as smasher sand. In the event that it is conceivable to utilize this squashed stone residue in making cement and mortar by fractional/full substitution of regular stream sand, at that point this won't just spare the expense of development and yet it will take care of the issue of transfer of this residue.

Revised Manuscript Received on October 22, 2019.

Anish C, Department of Civil Engineering, Bharath Institute of Higher Education and Research, Chennai , India. Email anishdavidpaul@gmail.com

Sathish Kumar K, Department of Civil Engineering, Bharath Institute of Higher Education and Research, Chennai , India. Email: sathish_4549@yahoo.co.in

Rajesh S, Department of Civil Engineering, Bharath Institute of Higher Education and Research, Chennai, India. Email: rajeshskr06@gmail.com
We are done our task work in Cognizant IT Park(ELCOT) sholinganallur. A task of L\&T developments, Chennai. We joined silica vapor and fly debris in the solid. we looked at the qualities of both silica exhaust and fly debris concrete with regular cement.

\section{OBJECTIVE}

1. To investigate the workability $\&$ strength characteristics . 2. To compare the results with the conventional concrete.

3. The mixes of grade $\mathrm{M} 30$ by replacing $0,5,10$, and 15 percent of the mass of bond with silica smoke and fly debris utilizing a superplasticizer.

4. Likewise, an endeavor is made to locate the ideal bond substitution level by SF for better quality attributes of cement. 5. To look at the consequences of both the silica rage fly debris concrete with the customary cement[16]-[22].

\section{A. Scope}

This investigation centers around the properties of Silica exhaust on elite cement to yield prior quality. And furthermore researched the investigation of fly debris properties in cement to yield quality and cost by monetarily. Among the properties we researched for the compressive quality on concrete while keeping up the usefulness.

\section{B. Silica fume}

Fly debris is a mechanical waste and a material of puzzolanic trademark happening because of consuming the pummeled coal in the warm power plants. In the development part, the fly debris is utilized in the creation of bond as an added substance material, underway of cement rather than a portion of the concrete or rather than a portion of the fine total, as a base and sub-base material in thruway development, as a filling material in dams, in holding dividers, and for generation of light development materials[23]-[29].

\section{RESULT AND DISCUSSION}

Pressure test was done on cubic examples. The size of the specimen is $150 \mathrm{~mm} \times 150 \mathrm{~mm} \times 150 \mathrm{~mm}$. three sample for each age of concrete were tried and the quality was acquired by normal. The individual variety of example was not more than $\pm 15 \%$ of the normal. The example put away in water were tried quickly on the expulsion from matrix were cleared off the examples and any anticipating pins evacuated. The dimension of the specimen and their weight were recorded before testing.

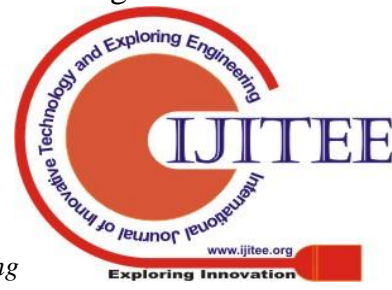


The pressure testing machine was cleaned off and again different materials, which may interact with the pressure plates. While setting the 3D shapes in the machine, care was taken to such an extent that the heap was applied to the contrary sides of the 3D shapes and not to top and base[30]-[34]

\begin{tabular}{|c|c|c|c|c|}
\hline Material & $\begin{array}{c}\text { strength } \\
\mathrm{N} / \mathrm{mm} 2\end{array}$ & $\begin{array}{c}\text { strength } \\
\mathrm{N} / \mathrm{mm} 2\end{array}$ & $\begin{array}{c}\text { strength } \\
\mathrm{N} / \mathrm{mm} 2\end{array}$ & $\begin{array}{c}\text { Avg. } \\
\text { strength } \\
\mathrm{N} / \mathrm{mm} 2\end{array}$ \\
\hline Fly ash 5\% & 28.64 & 27.48 & 28.46 & 28.19 \\
\hline Fly ash10\% & 25.28 & 25.16 & 24.98 & 25.14 \\
\hline Fly ash15\% & 23.24 & 23.16 & 23.98 & 23.46 \\
\hline $\begin{array}{c}\text { Conventional } \\
\text { concrete }\end{array}$ & 24.48 & 23.52 & 22.46 & 23.48 \\
\hline
\end{tabular}

Table - 1 Compressive Strength Of Concrete Table 1, 3 Days

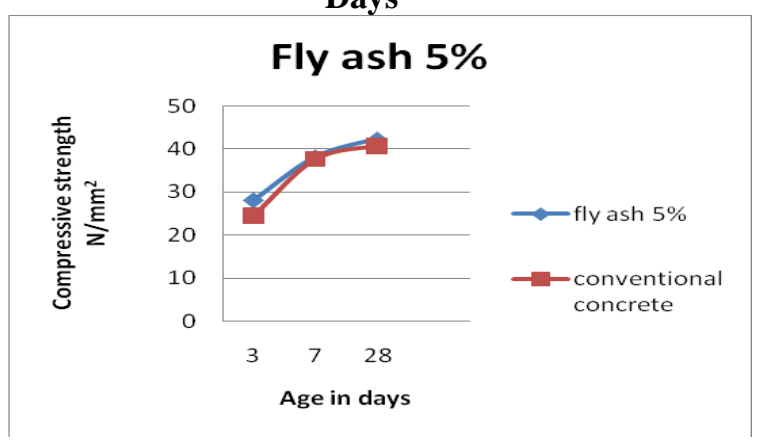

Figure - 1 Compressive Strength Of Concrete Table 1, 3 Days

\begin{tabular}{|c|c|c|c|c|}
\hline Material & $\begin{array}{c}\text { strength } \\
\mathrm{N} / \mathrm{mm} 2\end{array}$ & $\begin{array}{c}\text { strength } \\
\mathrm{N} / \mathrm{mm} 2\end{array}$ & $\begin{array}{c}\text { strength } \\
\mathrm{N} / \mathrm{mm} 2\end{array}$ & $\begin{array}{c}\text { Avg. } \\
\text { strength } \\
\mathrm{N} / \mathrm{mm} 2\end{array}$ \\
\hline Fly ash 5\% & 38.49 & 37.86 & 38.21 & 38.18 \\
\hline Hy ash10\% & 37.07 & 38.35 & 36.03 & 37.15 \\
\hline Fy ash15\% & 29.99 & 29.38 & 33.57 & 30.98 \\
\hline $\begin{array}{c}\text { Conventional } \\
\text { concrete }\end{array}$ & 38.51 & 37.57 & 36.84 & 37.64 \\
\hline
\end{tabular}

Table - 2 Compressive Strength Of Concrete Table 2, 7 Days

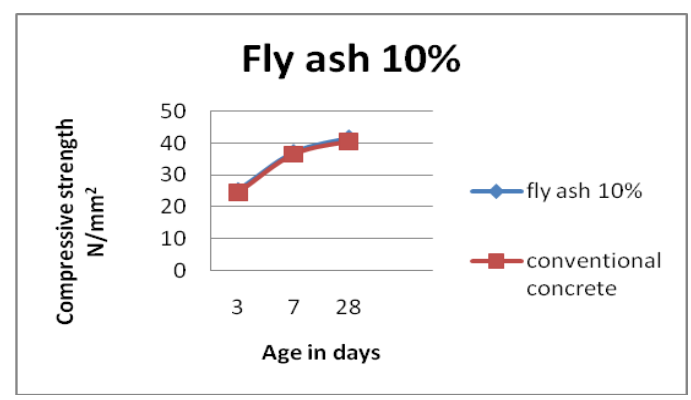

Figure - 1 Compressive Strength Of Concrete Table 2, 7 days

\begin{tabular}{|c|c|c|c|c|}
\hline Material & $\begin{array}{c}\text { strength } \\
\mathrm{N} / \mathrm{mm} 2\end{array}$ & $\begin{array}{c}\text { strength } \\
\mathrm{N} / \mathrm{mm} 2\end{array}$ & $\begin{array}{c}\text { strength } \\
\mathrm{N} / \mathrm{mm} 2\end{array}$ & $\begin{array}{c}\text { Avg. } \\
\text { strength } \\
\mathrm{N} / \mathrm{mm} 2\end{array}$ \\
\hline Fly ash 5\% & 41.28 & 42.69 & 42.98 & 42.31 \\
\hline Fly ash10\% & 41.10 & 41.62 & 42.35 & 41.69 \\
\hline Fly ash15\% & 40.94 & 41.23 & 40.26 & 40.81 \\
\hline $\begin{array}{c}\text { Conventional } \\
\text { concrete }\end{array}$ & 40.23 & 41.68 & 40.14 & 40.68 \\
\hline
\end{tabular}

Table - 1 Compressive Strength Of Concrete Table 2, 14 Days

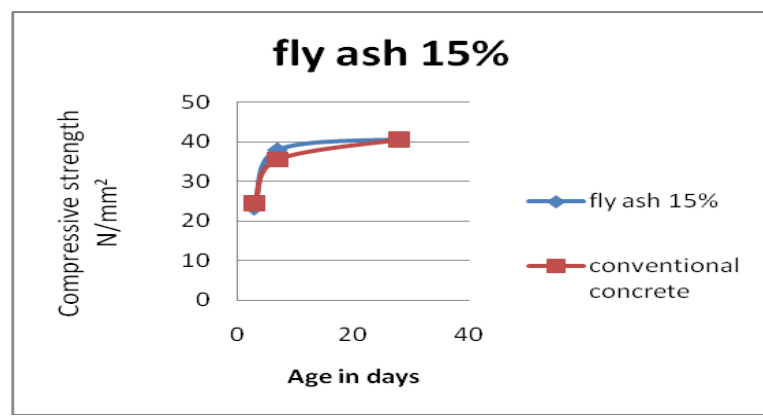

Figure - 1 Compressive Strength Of Concrete Table 2, 14 Days

\section{CONCLUSION}

Bond is in part supplanted with the silica smolder prompts increment in compressive quality for M30 evaluation of cement. From compressive quality for 3days, 7days and 28 days restoring period. when contrasted and the regular cement:

1. When comparing with conventional concrete $10 \%$ of fly ash replacement leads increase in the strength among the results.

2. And workability on the slump also has an good conditional value.

3. Both the physical and chemical properties has an compliance with the Cement.

4. Which reduce the heat of hydration in concrete.

5. It is economically saves cost by replacing the fly ash in the concrete.

\section{RECOMMENDATIONS}

1. It is suggested that testing of cement created with smaller scale silica and fly debris concrete be reached out to 56 or conceivably 90 days to additionally decide the pozzolanic capacity of the miniaturized scale silica and fly debris.

2. Volume substitution techniques are prescribed to examine the probability of creating high quality cement with small scale silica and fly debris.

3. Volume substitution techniques are prescribed to examine the probability of creating high quality cement with small scale silica and fly debris. 


\section{REFERENCES}

1. Iyappan L., Dayakar P., Identification of landslide prone zone for coonoortalukusing spatial technology, International Journal of Applied Engineering Research,V-9,I-22,PP-5724-5732, Y-2014.

2. Kumar J., Sathish Kumar K., Dayakar P.,Effect of microsilica on high strength concrete, International Journal of Applied Engineering Research,V-9,I-22,PP-5427-5432,Y-2014.

3. Dayakar P., Vijay Ruthrapathi G., Prakesh J., Management of bio-medical waste, International Journal of Applied Engineering Research,V-9,I-22,PP-5518-5526,Y-2014.

4. Swaminathan N., Dayakar P., Resource optimization in construction project, International Journal of Applied Engineering Research,V-9,I-22,PP-5546-5551,Y-2014

5. Venkat Raman K., Dayakar P., Raju K.V.B.,An experimental study on effect of cone diameters in penetration test on sandy soil, International Journal of Civil Engineering and Technology,V-8,I-8,PP-1581-1588,Y-2017.

6. Saritha B., Chockalingam M.P.,Photodradation of malachite green DYE using TIO2/activated carbon composite,International Journal of Civil Engineering and Technology,V-8,I-8,PP-156-163,Y-2017

7. Shendge R.B., Chockalingam M.P., Saritha B., Ambica A.,Swat modelling for sediment yield: A case study of Ujjani reservoir in Maharashtra, India,International Journal of Civil Engineering and Technology,V-9,I-1,PP-245-252,Y-2018

8. Chockalingam M.P., Balamurgan V.,Modernisation of an existing urban road-sector in Chennai, a case study report,International Journal of Civil Engineering and Technology,V-8,I-8,PP-1457-1467,Y-2017

9. Saritha B., Chockalingam M.P.,Adsorption study on removal of basic dye by modified coconut shell adsorbent, International Journal of Civil Engineering and Technology,V-8,I-8,PP-1370-1374,Y-2017

10. Saritha B., Chockalingam M.P.,Adsorptive removal of heavy metal chromium from aqueous medium using modified natural adsorbent,International Journal of Civil Engineering and Technology,V-8,I-8,PP-1382-1387,Y-2017

11. Chockalingam M.P., Palanivelraja S.,Retrospective analysis of a theoretical model used for forecasting future air quality near the north Chennai thermal power plant,International Journal of Civil Engineering and Technology,V-8,I-8,PP-1457-1467,Y-2017

12. Saritha B., Chockalingam M.P.,Photodegradation of methylene blue dye in aqueous medium by $\mathrm{Fe}-\mathrm{AC} / \mathrm{TiO} 2$ Composite,Nature Environment and Pollution Technology,V-17,I-4,PP-1259-1265,Y-2018

13. Shendge R.B., Chockalingam M.P., Kaviya B., Ambica A.,Estimates of potential evapotranspiration rates by three methods in upper Bhima Basin, In Maharashtra, India,International Journal of Civil Engineering and Technology,V-9,I-2,PP-475-480,Y-2018

14. Shendge R.B., Chockalingam M.P.,The soil and water assessment tool for Ujjani Reservoir,International Journal of Mechanical Engineering and Technology,V-9,I-2,PP-354-359,Y-2018

15. Shendge R.B., Chockalingam M.P.,A review on soil and water assessment tool,International Journal of Mechanical Engineering and Technology,V-9,I-2,PP-347-353,Y-2018

16. Sachithanandam P., Meikandaan T.P., Srividya T.,Steel framed multi storey residential building analysis and design,International Journal of Applied Engineering Research,V-9,I-22,PP-5527-5529,Y-2014

17. Meikandaan T.P., Ramachandra Murthy A.,Study of damaged RC beams repaired by bonding of CFRP laminates,International Journal of Civil Engineering and Technology,V-8,I-2,PP-470-486,Y-2017

18. Meikandaan T.P., Ramachandra Murthy A.,Retrofittng of reinforced concrete beams using GFRP overlays,International Journal of Civil Engineering and Technology,V-8,I-2,PP-423-439,Y-2017

19. Meikandaan T.P., Ramachandra Murthy A.,Flexural behaviour of RC beam wrapped with GFRP sheets,International Journal of Civil Engineering and Technology,V-8,I-2,PP-452-469,Y-2017

20. Meikandaan T.P., Murthy A.R.,Experimental study on strengthening of rc beams using glass Fiber,International Journal of Civil Engineering and Technology,V-9,I-11,PP-959-965,Y-2018

21. Meikandaan T.P., Hemapriya M.,Use of glass FRP sheets as external flexural reinforcement in RCC Beam,International Journal of Civil Engineering and Technology,V-8,I-8,PP-1485-1501,Y-2017

22. Saraswathy R., Saritha B.,Planning of integrated satellite township at Thirumazhisai,International Journal of Applied Engineering Research,V-9,I-22,PP-5558-5560,Y-2014

23. Saritha B., Ilayaraja K., Eqyaabal Z.,Geo textiles and geo synthetics for soil reinforcement,International Journal of Applied Engineering Research,V-9,I-22,PP-5533-5536,Y-2014
24. Ambica A., Saritha B., Changring G., Singh N B., Rajen M., Salman Md.,Analysis of groundwater quality in and around Tambaram taluk, Kancheepuram district,International Journal of Civil Engineering and Technology,V-8,I-8,PP-1362-1369,Y-2017

25. Arunya A., Sarayu K., Ramachandra Murthy A., Iyer N.R.,Enhancement of durability properties of bioconcrete incorporated with nano silica,International Journal of Civil Engineering and Technology,V-8,I-8,PP-1388-1394,Y-2017

26. Ilayaraja K., Krishnamurthy R.R., Jayaprakash M., Velmurugan P.M., Muthuraj S.,Characterization of the 26 December 2004 tsunami deposits in Andaman Islands (Bay of Bengal, India),Environmental Earth Sciences,V-66,I-8,PP-2459-2476,Y-2012

27. Ilayaraja K.,Morphometric parameters of micro watershed in Paravanar sub-basin, Cuddalore District,International Journal of Civil Engineering and Technology,V-8,I-8,PP-1444-1449,Y-2017

28. Ilayaraja K., Singh R.K., Rana N., Chauhan R., Sutradhar N.,Site suitability assessment for residential areas in south Chennai region using remote sensing and GIS techniques,International Journal of Civil Engineering and Technology,V-8,I-8,PP-1468-1475,Y-2017

29. Ilayaraja K., Reza W., Kumar V., Paul S., Chowdhary R.,Estimation of land surface temperature of Chennai metropolitan area using Landsat images,International Journal of Civil Engineering and Technology,V-8,I-8,PP-1450-1456,Y-2017

30. Chitra R.,Experimental study on beam using steel fiber and latex,International Journal of Civil Engineering and Technology,V-8,I-8,PP-1395-1403,Y-2017

31. Chitra R.,Analysis of traffic and management at Kovilambakkam intersection,International Journal of Civil Engineering and Technology,V-8,I-8,PP-1433-1443,Y-2017

32. Aswathy M.,Experimental study on light weight foamed concrete,International Journal of Civil Engineering and Technology,V-8,I-8,PP-1404-1412,Y-2017

33. Aswathy M.,Wastewater treatment using constructed wetland with water lettuce (Eichornia Crasipies),International Journal of Civil Engineering and Technology,V-8,I-8,PP-1413-1421,Y-2017

34. Kiruthiga K., Anandh K.S., Gunasekaran K, Assessment of influencing factors on improving effectiveness and productivity of construction engineers, 2015, International Journal of Applied Engineering Research, V - 10,I -17,p -13849-13854.

\section{AUTHORS PROFILE}

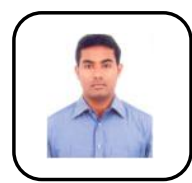

Anish C Assistant Professor, Department of Civil Engineering, Bharath Institute of Higher Education and Research, Chennai , India.

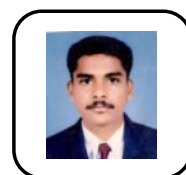

Sathish Kumar K Assistant Professor, Department of Civil Engineering, Bharath Institute of Higher Education and Research, Chennai, India.

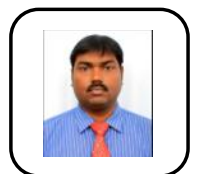

Rajesh S Assistant Professor, Department of Civil Engineering, Bharath Institute of Higher Education and Research, Chennai, India. 